\title{
Hereditary coproporphyria: incidence in a large English family*
}

\section{J ANDREWS $\dagger$, H ERDJUMENT + , AND D C NICHOLSON $\ddagger$}

From the †Department of Geriatric Medicine, West Middlesex University Hospital, Isleworth, Middlesex; and $\ddagger$ the Department of Chemical Pathology, King’s College Hospital Medical School, London SE5.

SUMMARY In a family inheriting the hereditary coproporphyria (HCP) gene, where 414 descendants have been traced through six generations and 135 members screened for faecal porphyrins, 27 subjects were found to have inherited the gene as well as the proband. Seven (six female and one male) in retrospect had probably previously suffered from a clinical attack of porphyria. Enzymological studies were carried out on 15 members and two unaffected parents and these results in general agreed with the faecal coproporphyrin readings.

Symptomatic illness is low in HCP and is almost always precipitated by drugs known to have an adverse effect on the condition. If the gene is inherited, an attack can occur at any time between puberty and old age, such as in the proband at 84 years. We have detected abnormal faecal coproporphyrin levels in members of this pedigree as young as 12 years and as old as 87 years.

Recommendations are given concerning the necessity of tracing relatives who may have inherited the gene and arranging for their biochemical screening and genetic counselling if indicated.

Dobriner ${ }^{1}$ first described the presence of excessive amounts of coproporphyrin isomer III in certain patients and the first clinical description was recorded in $1949 .^{2}$ Smaller family series have been reported by Haeger-Aronsen et $a l,{ }^{3}$ Dean and Kramer, ${ }^{4}$ and Lomholt and With. ${ }^{5}$ We report a family carrying the hereditary coproporphyria (HCP) gene traced through six generations. The proband was first diagnosed at the age of 84 years. A total of 414 living descendants of the proband's great-grandparents were traced and 135 subjects were screened for excessive porphyrin in their faeces on at least one occasion. Twenty-seven subjects were found to have inherited the condition, eight of whom had hitherto undiagnosed clinical illnesses which, in retrospect, were probably attacks of clinical porphyria. All but one had recently taken drugs known to precipitate clinical symptoms. Two other family members, judging from their medical history, had also previously had attacks.

\section{Methods}

TRACING RELATIVES

The extended family was traced and the great majority visited, and an appropriate medical and

*An extended version of this paper is available from the authors on request.

Received for publication 16 July 1983.

Accepted for publication 20 January 1984. drug history was taken. Porphyrin estimations on the faeces were then carried out on the oldest surviving members of each branch of the family and, if positive, all the next generation and their progeny, if indicated, were tested.

Of the proband's close relations, including first cousins, only five oldest surviving members of each branch were not tested, as they were all living abroad (fig 1); 18 were found to have inherited the gene. Of the proband's second cousins descended from her maternal great-aunt, all except 13 (seven living abroad and six refusals) were tested and nine were found to have inherited the gene (fig 2). All the descendants of the proband's maternal great-uncle were tested (14) and none was found to have inherited the gene (fig 3). The proband's maternal great-aunt and great-uncle married sibs.

\section{Biochemical studies}

FAECAL COPROPORPHYRIN ESTIMATIONS

The faeces were tested on receipt by post or stored at $-4^{\circ} \mathrm{C}$ until tested. Screening for faecal porphyrins was performed and if positive assayed quantitatively for faecal copro- and protoporphyrins, urinary copro- and uroporphyrins, and urinary porphobilinogen (PBG) by the method of Rimington. ${ }^{6}$ The normal value for faecal coproporphyrin was taken as under $46 \mathrm{nmol} / \mathrm{g}$ dry weight. ${ }^{7}$ 
ENZYMOLOGICAL STUDIES

The proband and her son had skin biopsies performed for fibroblast culture to estimate the coproporphyrinogen oxidase activity. ${ }^{8}$ In other cases coproporphyrinogen oxidase estimations were carried out on the lymphocytes and activity expressed as nmol $\mathrm{CO}_{2} / \mathrm{h} / \mathrm{mg}$ protein according to the method of Elder and Evans. ${ }^{9}$

\section{Proband's clinical history}

The proband (III.2.8.5), diagnosed at the age of 84 ,

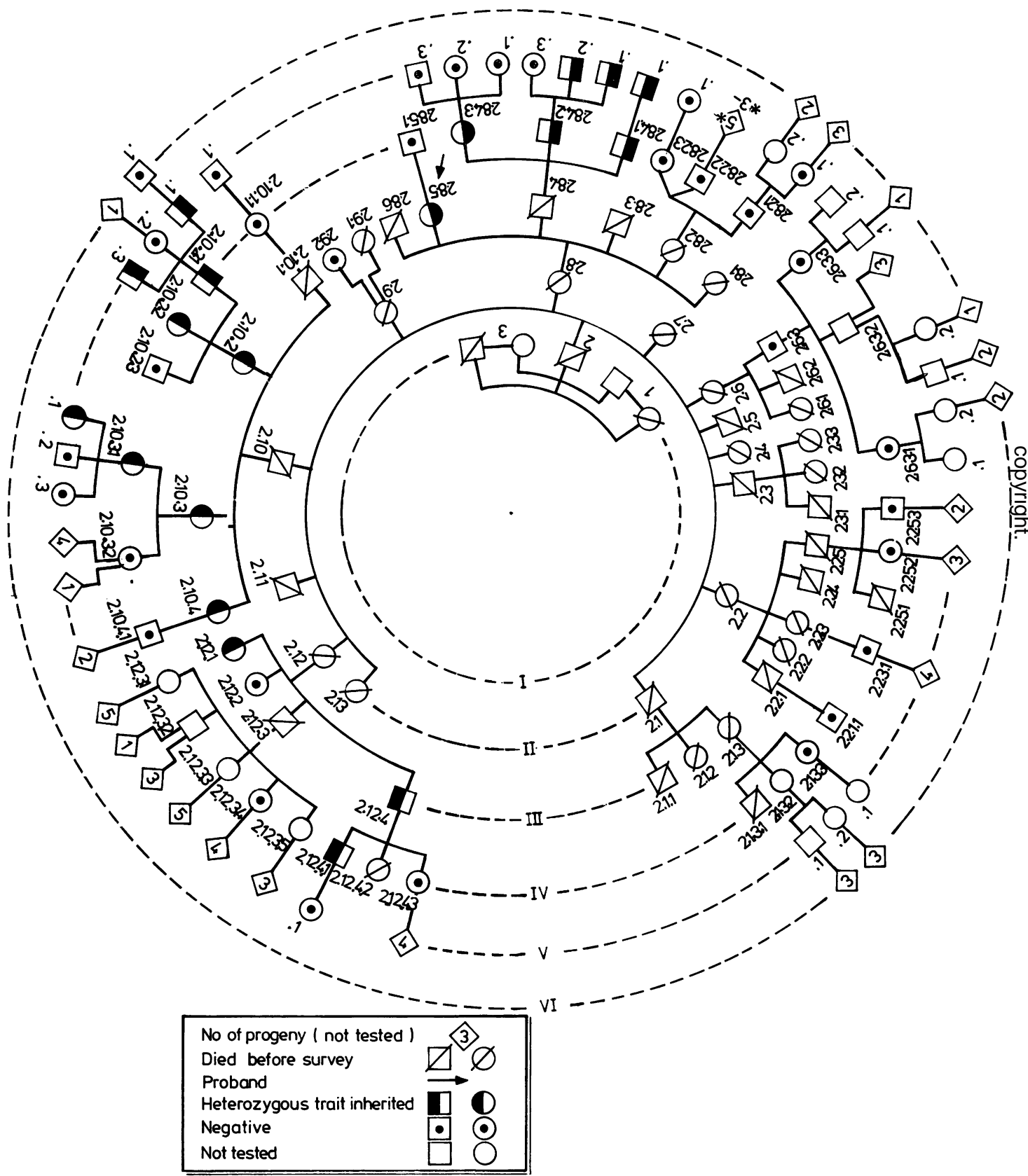

FIG 1 Proband's grandfather's pedigree. ${ }^{*}$ Five children, three of whom were tested and found negative. 


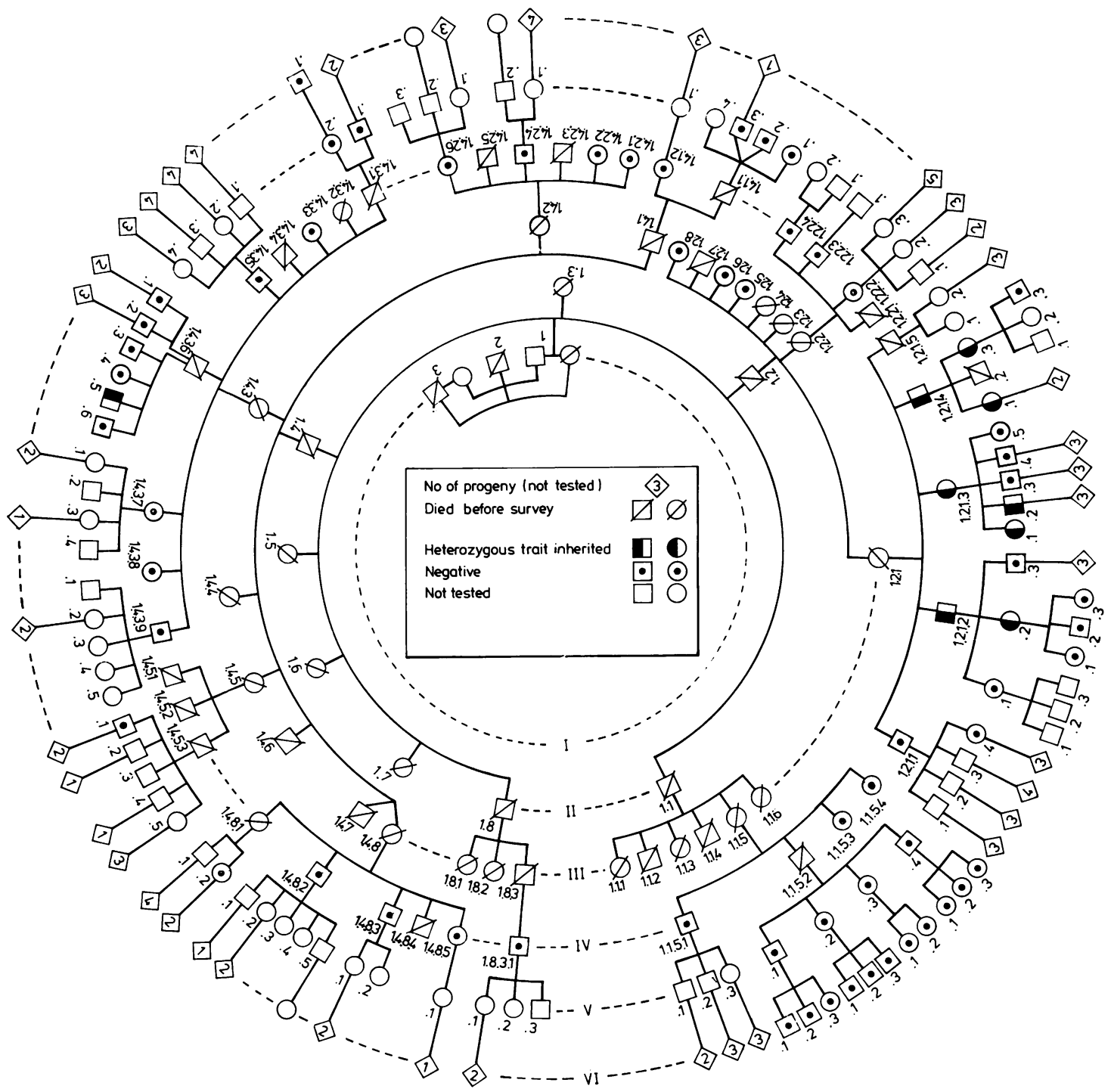

FIG 2 Proband's great-aunt's pedigree.

had always been well apart from chronic bronchitis and mild cardiac failure, the only previous drug history being antibiotics, diuretics, and digitalis. Alcohol intake had been minimal.

However, over the years she had complained of skin sensitivity ('prickly heat') and had fragile skin over the back of her hands. Two years before the diagnosis was made she became agitated and showed respiratory distress (without respiratory infection) a few days after an influenza vaccination. An attack of porphyria, possibly precipitated by vaccination, has been reported. ${ }^{10}$

Five months before diagnosis she had a suspected fractured femur and became very confused, agitated, and dehydrated after admission to hospital. Complications included an artificial pneumothorax, surgical emphysema, and haematuria. She was prescribed diazepam and nitrazepam and, owing to inadequate respiratory function at the time thought to be due to pneumonia or pulmonary embolism, she was artificially ventilated. She gradually recovered and returned home, somewhat mentally impaired.

Two months later she was admitted elsewhere for a confirmed fractured femur. After fracturing both femora and undergoing three operations on her hips, she was receiving the same drugs again and also 
brandy. She became manic, hallucinated, photophobic, and developed mononeuritis multiplex (respiratory distress, paresis of both legs and one arm, bilateral foot drop, and unilateral wrist drop). Abdominal pain was not present. After diagnosis and omission of incriminating drugs the patient's mental and physical condition improved somewhat, the arm recovering completely and the legs partially.

Three months later her first faecal coproporphyrin reading was $2713 \mathrm{nmol}$, her faecal protoporphyrin was $124 \mathrm{nmol} / \mathrm{g}$ dry weight, and the urinary coproporphyrin and uroporphyrin were $1701 \mathrm{nmol}$ and $47 \mathrm{nmol} / 24$ hours, respectively. The urinary PBG was $7.5 \mathrm{mmol} / 24$ hours. Re-testing of the faeces 2 years later showed little change in faecal porphyrin levels although her urinary uroporphyrin was double that found previously. The coproporphyrinogen oxidase activity in her fibroblasts was found to be half that of normal controls as earlier reported. ${ }^{8}$

\section{Manifestations of the disease in the family}

\section{SYMPTOMS}

Skin fragility occurred in four subjects and confusional states in three, while two each had muscle paresis, photophobia, and hallucinations. Abdominal pain was not present. The proband's elder sister (III.2.8.1) died at 48 following an attack of acute abdominal pain, appendicitis being queried. The death certificate given in 1929 by her uncle (II.2.10), who was her family doctor, was spinal myelitis. The proband's youngest brother (III.2.8.6) had a sensitive skin which was exacerbated by wearing rough khaki in the First World War.
EXCITATORY CAUSES FOR CLINICAL SYMPTOMS Drugs, infection, and fasting are known to cause both worsening of the metabolic picture manifesting itself biochemically in the faeces and urine, and the appearance of clinical symptoms. ${ }^{11}$ Neither infection nor fasting could be identified as precipitating causes in any members of the family. However, of those who had previously produced clinical symptoms likely to have been caused by an attack of porphyria, all except one did so following the taking of drugs known to exacerbate the condition, for example, alcohol, barbiturates, dichloralphenazone, diazepam, nitrazepam, methyl dopa, sulphonamides, and possibly Eskornade (isopropamide, phenylpropanolamine $\mathrm{HCl}$, diphenylpyraline $\mathrm{HCl}$ ), not previously reported as a precipitating compound. ${ }^{12}$

\section{Biochemical results}

\section{INHERITANCE OF THE GENE}

The least number of subjects in each generation who either had abnormally raised levels of faecal coproporphyrin or produced progeny who did, gave figures of $2,5,9,11$, and 12 for generations I, II, III, $I V$, and $V$ respectively. In the fifth generation there are four subjects who are children of positive parents who have not been tested, or re-tested after adolescence, through lack of access or refusal. As there is a $50 \%$ chance of inheriting this autosomal dominant condition the estimated number of those inheriting the gene in generation $\mathrm{V}$ would be $12+2=14$. In generation VI there are seven children of biochemically positive parents who have not been screened through lack of access, or refusal on the part of the parents, the eldest being born in 1967.

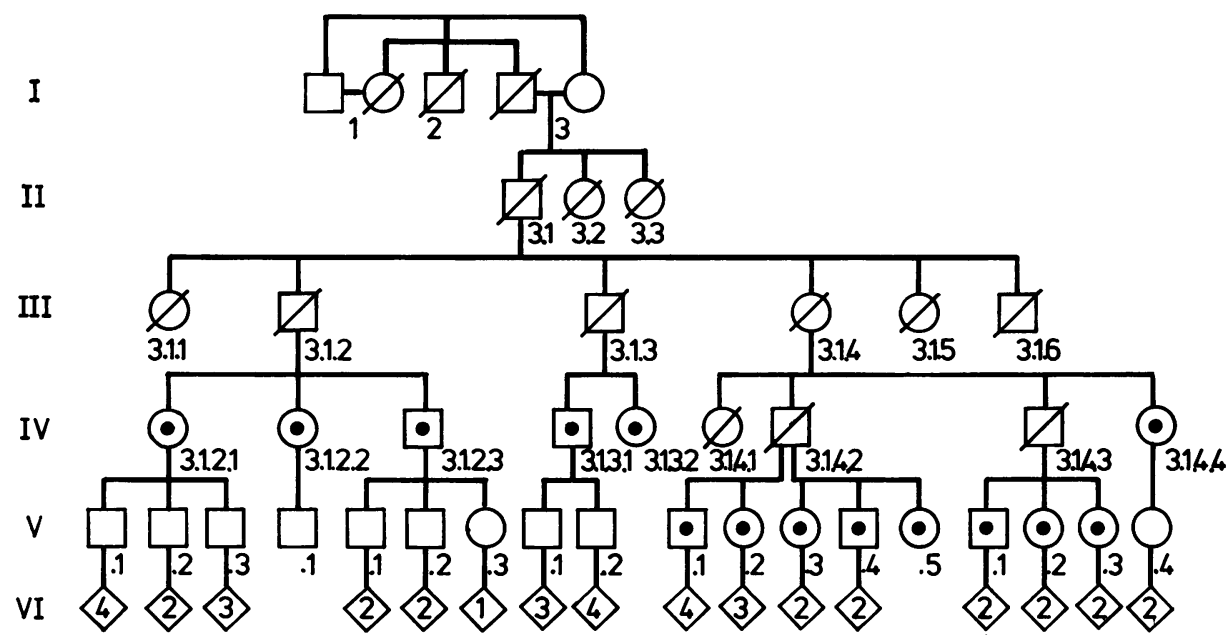

FIG 3 Proband's great-uncle's pedigree. (See fig 1 or 2 for key.) 
Twenty progeny of subjects who had normal levels of porphyrins in their faeces were screened again for diverse reasons and all were shown not to have raised levels.

There was a sufficient number of faecal coproporphyrin estimations (as opposed to faecal porphyrin screening tests) to give some indication of the 'normal' and 'abnormal' levels found in this particular family. There appears to be a cut-off point between those who seem likely to be positive from clinical and genetic information and those who are negative (fig 4). Those of the family who became clinically ill generally had very high levels of faecal coproporphyı ins but not higher than some symptomless positive subjects.

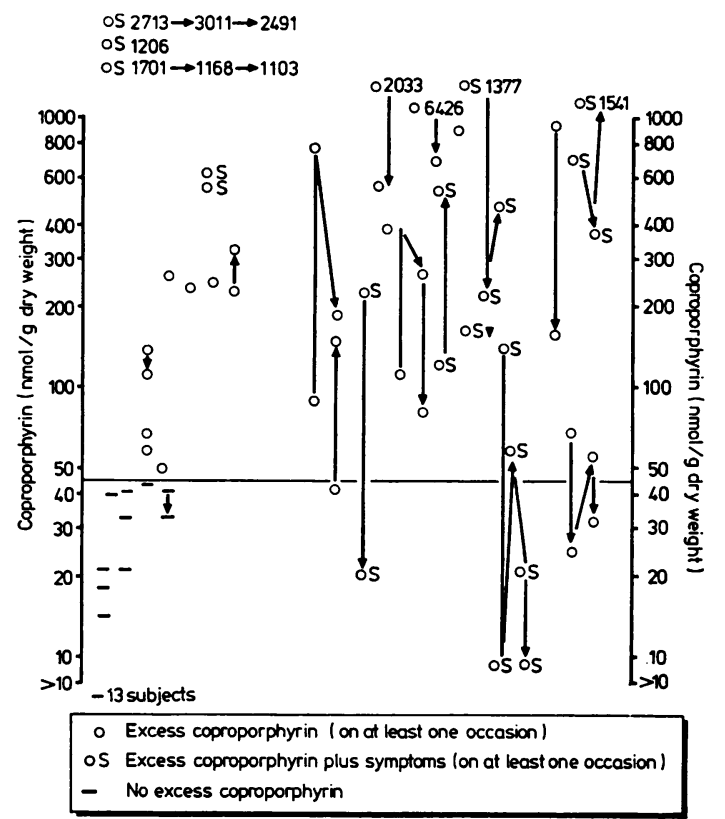

FIG 4 Faecal coproporphyrin estimations in individual subjects. (Joined lines with arrow's represent sequential results in the same subject.)
ILLNESSES OCCURRING DURING THE SURVEY OF A POSITIVE SUBJECT

A recently widowed female aged 72 (III.2.10.4.), a diagnosed porphyric receiving other hypotensive therapy, was prescribed methyl dopa. Her original levels were: faecal coproporphyrin $550 \mathrm{nmol} / \mathrm{g}$ dry weight; protoporphyrin $282 \mathrm{nmol} / \mathrm{g}$ dry weight; urinary coproporphyrin $358 \mathrm{nmol} / \mathrm{l}$; uroporphyrin $18 \mathrm{nmol} / \mathrm{l}$. She developed an influenza-like illness, became depressed, hallucinated, and had pain, weakness, and aching in her legs. Porphyrin studies were not performed then. After being taken off the methyl dopa she gradually recovered completely.

ILLNESSES OCCURRING IN POSITIVE SUBJECTS BEFORE THE SURVEY

In each case the presumed illness was triggered by drugs which, apart from Eskornade, are known to excite acute systemic porphyric symptoms.

(1) A widow (III.2.10.2), aged 79, was taking dichloralphenazone as a sleeping tablet. She had a moderate degree of blistering on her forearms and legs and on discontinuation of the drug the skin improved considerably. Her initial faecal coproporphyrin level was high while on dichloralphenazone and rapidly returned to normal on its withdrawal (table 1).

(2) The daughter of III.2.10.2, IV.2.10.2.2, was only screened because her mother initially had raised positive coproporphyrin levels in the faeces which would not have been diagnosed if her mother had not been on dichloralphenazone. As an adolescent she developed nausea after sulphonamide therapy and at the age of 33 years was prescribed Eskornade. She subsequently became sick, weak, and dizzy, went to bed for 14 days, became nauseated, vomited, suffered from ataxia and backache, was photophobic, and had some degree of facial paresis. She continued to have some skin fragility without ingestion of any drug known to excite latent porphyria. She has since been prescribed oxazepam and amitryptyline, the latter drug being capable of exciting latent cases. Her faecal coproporphyrin levels have been between 1701 and $1103 \mathrm{nmol} / \mathrm{g}$ dry

TABLE 1 Faecal, urinary, and erythrocyte porphyrin levels of III.2.10.2.

\begin{tabular}{|c|c|c|c|c|c|c|}
\hline \multirow[t]{2}{*}{ Year } & \multicolumn{2}{|c|}{ Faeces (nmol/g dry wt) } & \multicolumn{3}{|l|}{ Urine $($ nmol/l) } & \multirow{2}{*}{$\begin{array}{l}\text { Erythrocytes } \\
\text { (nmol/l packed } R B C) \\
\text { Coproporphyrin }\end{array}$} \\
\hline & Coproporphyrin & Protoporphyrin & Coproporphyrin & Uroporphyrin & $P B G$ & \\
\hline \multicolumn{7}{|c|}{ On dichloralphenazone } \\
\hline 1975 & 173 & 36 & 76 & 23 & No excess & - \\
\hline 1977 & 149 & 102 & 218 & - & - & 6910 \\
\hline \multicolumn{7}{|c|}{ After discontinuation of dichloralphenazone } \\
\hline 1977 & 8 & 2 & 182 & No excess & No excess & - \\
\hline 1981 & 52 & - & - & - & - & - \\
\hline $1982(\mathrm{a}$ & 21 & 147 & - & - & - & - \\
\hline (b & 7 & 23 & No excess & No excess & Excess present & - \\
\hline
\end{tabular}


weight, considerably higher than her mother's have ever been.

(3) IV.2.10.3.1 gave faecal coproporphyrin readings of between 400 and $1541 \mathrm{nmol} / \mathrm{g}$ dry weight. At the age of 14 she became mildly disorientated while taking sulphonamides for a respiratory tract infection and also after barbiturate therapy on a different occasion.

(4) IV. 2.8.4.3, a niece of the proband, has had high levels of coproporphyrins in both the faeces and urine and in the past has suffered hallucinations and nightmares after taking dichloralphenazone. Her faecal coproporphyrin in 1979 was $1377 \mathrm{nmol} / \mathrm{g}$ dry weight, and since then has never been lower than $228 \mathrm{nmol} / \mathrm{g}$ dry weight. Her urinary coproporphyrin was originally $438 \mathrm{nmol} / 1$.

(5) V.1.2.1.4.3 also suffered from the ill effects of dichloralphenazone, this time with paraethesiae. Her faecal coproporphyrin level was $642 \mathrm{nmol} / \mathrm{g}$ dry weight. Her sister (V.1.2.1.4.1) also had a raised faecal coproporphyrin level at $68 \mathrm{nmol} / \mathrm{g}$ dry weight.

(6) V.1.4.3.6.5 had suffered from nightmares following excessive ethyl alcohol consumption on three occasions, but has otherwise suffered no symptoms. His initial faecal coproporphyrin was $215 \mathrm{nmol} / \mathrm{g}$ dry weight in 1977 but only $21 \mathrm{nmol}$ in 1982.

\section{BIOCHEMICAL LEVELS OF CLOSE \\ RELATIONS OF THE PROBAND}

All the proband's sibs had died by the time the survey was carried out, but two of her nephews and one niece, the children of an elder brother, had high faecal coproporphyrin levels. The niece has already been referred to (IV.2.8.4.3) and the nephews (IV.2.8.4.1 and IV.2.8.4.2) had levels of faecal coproporphyrin reaching $2033 \mathrm{nmol}$ and 6246 $\mathrm{nmol} / \mathrm{g}$ dry weight respectively, without either suffering any untoward symptoms.

\section{UNEXPLAINED SYMPTOMS IN PATIENTS WHO}

HAVE APPARENTLY NOT INHERITED THE GENE A member of the branch of the family (IV.3.1.3.2) who have apparently not inherited the gene reacted to local anaesthetics and Eskornade. An anaesthetist queried porphyria. Examination of her faeces was negative.

V.1.2.1.1.4, who had one aunt, two uncles, and five cousins with the gene, gave a history of severe abdominal pains over 10 years which have now ceased. Her father's faeces showed no excess coproporphyrin on two separate occasions and the subject herself proved negative on screening.

\section{AGE AT BIOCHEMICAL EVIDENCE \\ OF INHERITING THE GENE \\ Adolescents}

Some of the progeny of parents who have inherited this gene were initially tested in the prepubertal and immediate post-pubertal years (table 2). The prepubertal members have all been found not to have excess coproporphyrins in the faeces.

Females normal at the ages of 5, 8,11, 12, 13, and 13 were all normal at the ages of $13,14,18,18,21$, and 20 respectively. Similarly, males normal at the ages of 6,11 , and 14 have still remained within the range of normal at 15,17 , and 21 respectively.

However, one male (V.2.8.4.2.1) had a level of 42 nmol coproporphyrin/g dry weight in the faeces at the age of 15 , and $149 \mathrm{nmol} / \mathrm{g}$ dry weight at 23 years. His brother (V.2.8.4.2.2) had a quantitative result of $67 \mathrm{nmol} / \mathrm{g}$ dry weight at the age of 12 , levels of 28 $\mathrm{nmol}$ and $54 \mathrm{nmol} / \mathrm{g}$ dry weight at 20 years on two separate occasions, and a level of $33 \mathrm{nmol}$ at the age of 21.

One female (V.2.10.3.1.1) had an initial faecal coproporphyrin level of $127 \mathrm{nmol} / \mathrm{g}$ dry weight at 17 years and $524 \mathrm{nmol} / \mathrm{g}$ dry weight at 24 years of age. She is now taking the contraceptive pill but has had no adverse symptoms to date, apart from a fragile skin.

TABLE 2 Young progeny of parents with excess coproporphyrin in their faeces ( $\mathrm{nmol} / \mathrm{g}$ dry wt).

\begin{tabular}{|c|c|c|c|c|c|c|c|c|c|c|c|c|}
\hline No & Sex & $\begin{array}{l}\text { Year of } \\
\text { birth }\end{array}$ & 1974 & 1975 & 1976 & 1977 & 1978 & 1979 & 1980 & 1981 & 1982 & 1983 \\
\hline V.2.8.4.1.1 & $\mathbf{M}$ & 1961 & 107 & & & & & 32 & & & & \\
\hline V.2.8.4.2.1 & $\mathbf{M}$ & 1959 & 42 & & & & & & & & 149 & \\
\hline V.2.8.4.2.2 & $\mathbf{M}$ & 1962 & 67 & & & & & & & & $25 \& 54$ & 33 \\
\hline V.2.8.4.2.3 & $\mathbf{F}$ & 1969 & NE & & & & & & & & $\mathrm{NE}$ & \\
\hline V.2.8.4.3.1 & $\mathbf{F}$ & 1959 & NE & & & & & & & & & \\
\hline V.2.8.4.3.2 & $\mathbf{F}$ & 1961 & NE & & & & & & & & 15 & \\
\hline V.2.8.4.3.3 & $\mathbf{M}$ & 1968 & NE & & & & & & & & & $\mathrm{NE}$ \\
\hline V.2.10.3.1.1 & $\mathrm{F}$ & 1958 & & 127 & & & & & & & 524 & \\
\hline V.2.10.3.1.2 & $\mathbf{M}$ & 1961 & & NE & & & & & & & NE & \\
\hline V.2.10.3.1.3 & $\mathrm{F}$ & 1964 & & 5 & & & & & & & NE & \\
\hline V.2.12.4.2.1 & $\mathbf{F}$ & 1963 & & & $\mathrm{NE}$ & & & & & & & NE \\
\hline VI.1.2.1.2.2.1 & $\mathrm{F}$ & 1964 & & & $\mathrm{NE}$ & & & & & & NE & \\
\hline VI.1.2.1.2.2.2 & $\mathbf{M}$ & 1965 & & & NE & & & & & & NE & \\
\hline VI.1.2.1.2.2.3 & $\mathrm{F}$ & 1968 & & & $\mathrm{NE}$ & & & & & & $\mathrm{NE}$ & \\
\hline VI.1.2.1.4.3.3 & $\mathbf{M}$ & 1974 & & & & & 8 & & & & & \\
\hline
\end{tabular}

$\mathrm{NE}=$ no excess. 
The elderly

Three patients were first identified and diagnosed as having inherited the gene excreting excess coproporphyrins in the faeces in their $80 \mathrm{~s}$ and five more in their 70s. Excluding the proband, of those subjects first diagnosed over 70, four had faecal coproporphyrin levels over $400 \mathrm{nmol}$ and two over 900 $\mathrm{nmol} / \mathrm{g}$ dry weight, none having symptomatic illness at the time of testing.
Table 3 shows the age at diagnosis of those inheriting the gene and the age of any symptoms manifesting themselves in addition to possible excitatory drug incrimination.

\section{Enzymology results}

The proband's (III.2.8.5) fibroblast coproporphyrinogen oxidase showed reduced enzyme activity

TABLE 3 Details of subjects inheriting the trait.

\begin{tabular}{|c|c|c|c|c|c|}
\hline No & Sex & $\begin{array}{l}\text { Date of } \\
\text { birth }\end{array}$ & $\begin{array}{l}\text { Age diagnosed } \\
\text { biochemically }\end{array}$ & $\begin{array}{l}\text { Age symptoms } \\
\text { presented }\end{array}$ & Drugs incriminated \\
\hline III.2.12.1 & $\mathbf{F}$ & 1888 & 87 & 一 & 一 \\
\hline III.2.8.5 (Proband) & $\mathbf{F}$ & 1889 & 84 & 84 & Diazepam, nitrazepam, alcohol \\
\hline III.2.12.4 & $\mathbf{M}$ & 1895 & 87 & 二 & 二 \\
\hline III.2.10.2 & $\mathbf{F}$ & 1896 & 79 & 77 & Dichloralphenazone \\
\hline III.2.10.3 & $\mathbf{F}$ & 1898 & 77 & 一 & - \\
\hline III.2.10.4 & $\mathbf{F}$ & 1903 & 72 & 74 & Methyl dopa \\
\hline IV.1.2.1.2 & $\mathbf{M}$ & 1904 & 73 & 一 & 一 \\
\hline IV.1.2.1.3 & $\mathbf{F}$ & 1906 & 71 & - & 一 \\
\hline IV.1.2.1.4 & $\mathbf{M}$ & 1908 & 69 & - & - \\
\hline IV.2.8.4.1 & $\mathbf{M}$ & 1927 & 48 & - & 一 \\
\hline IV.2.8.4.2 & $\mathbf{M}$ & 1928 & 47 & 一 & 一 \\
\hline IV.2.8.4.3 & $\mathbf{F}$ & 1929 & 49 & 35 & Dichloralphenazone \\
\hline IV.2.10.3.1 & $\mathbf{F}$ & 1930 & 45 & 14 & Sulphonamides, barbiturates \\
\hline IV.2.10.2.2 & $\mathbf{F}$ & 1931 & 44 & 33 & Sulphonamides, Eskornade \\
\hline IV.2.12.4.1 & $\mathbf{M}$ & 1934 & 41 & - & - \\
\hline V.1.2.1.2.2 & $\mathbf{F}$ & 1935 & 37 & - & 一 \\
\hline V.1.2.1.3.1 & $\mathbf{F}$ & 1936 & 46 & - & - \\
\hline V.1.2.1.3.2. & $\mathbf{M}$ & 1938 & 37 & 一 & - \\
\hline V.1.2.1.4.1 & $\mathbf{F}$ & 1941 & 36 & 一 & - \\
\hline V.1.2.1.4.3 & $\mathbf{F}$ & 1947 & 30 & 25 & Dichloralphenazone, barbiturates \\
\hline V.2.10.2.1.1 & $\mathbf{M}$ & 1948 & 27 & - & — \\
\hline V.2.10.2.1.3 & $\mathbf{M}$ & 1953 & 23 & 一 & - \\
\hline V.1.4.3.6.5 & $\mathbf{M}$ & 1955 & 22 & 26 & Alcohol \\
\hline V.2.10.3.1.1 & $\mathbf{F}$ & 1958 & 17 & - & - \\
\hline V.2.8.4.2.1 & $\mathbf{M}$ & 1959 & 23 & 一 & - \\
\hline V.2.8.4.1.1 & $\mathbf{M}$ & 1961 & 13 & - & - \\
\hline V.2.8.4.2.2 & $\mathbf{M}$ & 1962 & 12 & 一 & 一 \\
\hline
\end{tabular}

IV.2.10.2.1 refused to be tested. His mother and his two children inherited the trait.

TABLE 4 Relationship between faecal coproporphyrin studies and lymphocyte coproporphyrinogen oxidase activity.

\begin{tabular}{|c|c|c|c|c|c|c|}
\hline \multirow[t]{2}{*}{ No } & \multicolumn{5}{|c|}{ Faecal coproporphyrin (nmol/g dry wt) } & \multirow{2}{*}{$\begin{array}{l}\text { L.ymphocyte } \\
\text { coproporphyrinogen } \\
\text { oxidase }\left(\text { nmol } \mathrm{CO}_{2} / \mathrm{h} / \mathrm{mg}\right. \\
\text { protein) }\end{array}$} \\
\hline & 1974 & 1977 & $\begin{array}{l}1982 \\
(a)\end{array}$ & $\begin{array}{l}1982 \\
(b)\end{array}$ & 1983 & \\
\hline $\begin{array}{l}\text { V.1.2.1.2.2 } \\
\text { VI.1.2.1.2.2.1 } \\
\text { VI.1.2.1.2.2.2 } \\
\text { VI.1.2.1.2.2.3 } \\
\text { Unaffected parent }\end{array}$ & $\begin{array}{l}\bar{z} \\
\bar{z}\end{array}$ & $\begin{array}{l}234 \\
\text { No excess } \\
\text { No excess } \\
\text { No excess } \\
-\end{array}$ & $\begin{array}{l}317 \\
\text { No excess } \\
\text { No excess } \\
\text { No excess } \\
-\end{array}$ & $\begin{array}{l}\text { 二 } \\
\text { - }\end{array}$ & $\begin{array}{l}\text { 二 } \\
\text { - }\end{array}$ & $\begin{array}{l}0.06 \\
0.11 \\
0.16 \\
0.15 \\
0.16\end{array}$ \\
\hline $\begin{array}{l}\text { IV.2.8.4.2 } \\
\text { V.2.8.4.2.1 } \\
\text { V.2.8.4.2.2 } \\
\text { V.2.8.4.2.3 } \\
\text { Unaffected parent }\end{array}$ & $\begin{array}{c}6426 \\
43 \\
67 \\
\text { No excess } \\
-\end{array}$ & $\begin{array}{l}\bar{Z} \\
\bar{z} \\
=\end{array}$ & $\begin{array}{l}703 \\
149 \\
25 \\
\text { No excess } \\
-\end{array}$ & $\begin{array}{l}\bar{z} \\
54 \\
-\end{array}$ & $\begin{array}{l}\bar{Z} \\
\bar{z} \\
-\end{array}$ & $\begin{array}{l}0.07 \\
0.06 \\
0.10 \\
0.22 \\
0.21\end{array}$ \\
\hline $\begin{array}{l}\text { IV.1.2.1.3 } \\
\text { V.1.2.1.3.1 } \\
\text { V.1.2.1.3.5 }\end{array}$ & E & $\begin{array}{l}927 \\
\text { No excess } \\
\text { No excess }\end{array}$ & $\frac{164}{\bar{N}}$ & 二 & E & $\begin{array}{l}0.07 \\
0.08 \\
0.15\end{array}$ \\
\hline $\begin{array}{l}\text { III.2.12.4 } \\
\text { IV.2.12.4.1 }\end{array}$ & 二 & 二 & $\begin{array}{l}\text { No excess } \\
129\end{array}$ & $\begin{array}{r}50 \\
114\end{array}$ & - & $\begin{array}{l}0.06 \\
0.06\end{array}$ \\
\hline
\end{tabular}


suggesting HCP while the estimation on her son (IV.2.8.5.1) showed a normal reading.

Table 4 shows the faecal coproporphyrin levels and lymphocyte coproporphyrin oxidase activity results in four branches of the family. The enzyme activity readings fall, generally speaking, into two categories except for two 'low normal' results (V.2.8.4.2.2 and VI.1.2.1.2.2.1).

\section{Discussion}

We report the largest family with hereditary coproporphyria investigated so far. It was first recognised as an autosomal dominant condition in $1955 .^{13}$ The mortality in undiagnosed attacks of hepatic porphyria can approach $10 \%$. In a 1977 paper $^{14}$ over one-third of cases reported had clinical symptoms but it was primarily describing patients with porphyric attacks rather than the incidence in a family. Table 3 records the age at diagnosis and the drugs incriminated in precipitating clinical porphyria.

\section{SEX INCIDENCE}

The sex incidence of those inheriting the gene is approximately equal but the sex incidence for those producing symptoms is far from so, six being female and one male. In acute hepatic porphyrias, Finnish workers ${ }^{15}$ reported that $75 \%$ of cases with symptoms were females.

\section{AGE AT DIAGNOSIS}

A subject in this series is the youngest ever reported to have an excess of faecal coproporphyrin at the age of 12. Haeger-Aronsen $e t a l^{3}$ and Grandchamp and Nordmann ${ }^{16}$ have reported females inheriting the gene at the ages of 13 and 14 . We record the oldest known subjects found to have inherited the gene, three being over the age of 80 . In all, eight members of the family were first detected and diagnosed over the age of 70 . This strongly suggests that without excitation by drugs the condition can run a benign course and is compatible with longevity.

VARIATIONS IN RESULTS

Variation in faecal coproporphyrin levels for the same post-pubertal subjects, not on any excitatory drug and tested on different occasions, has been reported by Cochrane and Goldberg ${ }^{17}$ and we report similar findings (fig 4).

Faecal specimens stored at $-4^{\circ} \mathrm{C}$ show only a moderate reduction of faecal coproporphyrin levels after considerable periods, $20 \%$ after 4 months in one case and $28 \%$ after 5 months in another.

Twenty post-pubertal close relatives of positive subjects who had initially been shown to have no excess faecal porphyrins were re-tested at a later date and were all confirmed negative.
As previous workers have shown on many occasions, abnormal faecal coproporphyrin levels do not occur until adolescence and large rises subsequently occur in those inheriting the gene, for example, V.2.8.4.2.1 and V.2.10.3.1.1 (table 2).

III.2.10.2 had faecal coproporphyrin levels of 173 $\mathrm{nmol}$ and $149 \mathrm{nmol} / \mathrm{g}$ dry weight while on dichloralphenazone which dropped to $8 \mathrm{nmol}$ on the drug being discontinued and remained below or near normal levels (table 1). Salem et al ${ }^{18}$ suggested that elderly patients, besides not being able to metabolise dichloralphenazone as well as younger patients, also show a reduced induction response.

Fig 4 illustrates other subjects showing large variations in faecal coproporphyrin levels, all being outside the accepted normal range, and at no time were any of these subjects taking drugs which have been shown to excite clinical porphyria.

\section{COMPARISON OF ENZYME AND}

FAECAL COPROPORPHYRIN READINGS

The enzyme results show two different groups, one which has inherited the gene and the other unaffected. The results in all but two cases fit in well with the faecal coproporphyrin levels, the two exceptions being one subject with normal faecal levels who would not be tested a second time (V.1.2.1.3.1) and proved to have abnormal enzyme levels. The other, who on the first occasion had no excess faecal coproporphyrin, on re-testing had a level of $50 \mathrm{nmol} / \mathrm{g}$ dry weight (III.2.12.4) but his son (IV.2.12.4.1) had abnormally raised faecal coproporphyrin levels and like his father had abnormal enzyme levels.

The two subjects who had 'low normal' enzyme activity (table 4) need repeat faecal coproporphyrin estimations carried out. V.2.8.4.2.2 had abnormally raised faecal coproporphyrin levels of $67 \mathrm{nmol}$ at the age of 12 , but one normal $(25 \mathrm{nmol})$ and one slightly raised $(54 \mathrm{nmol})$ level at the age of 20 , and $33 \mathrm{nmol} / \mathrm{g}$ dry weight at the age of 21 , showing that both his enzymological and faecal coproporphyrin levels were borderline. VI.1.2.1.2.2.1 had two normal faecal coproporphyrin levels at the age of 12 and 18.

\section{FAECAL COPROPORPHYRIN LEVELS IN} SUCCEEDING GENERATIONS

Lomholt and With ${ }^{4}$ suggested that the succeeding generations inheriting the gene appear to have lower levels of faecal coproporphyrin in each generation. In our study we have not been able to confirm this. Three adult daughters have been found to have higher levels of faecal coproporphyrin than their parent transmitting the gene (IV.2.10.2.2, IV.2.10.3.1, and V.1.2.1.4.3). 
Conclusions

\section{TRACING RELATIVES}

Although very time-consuming, tracing relatives of those who have been found to have inherited the gene is essential. As new drugs are continually becoming available it is not known whether a new drug is dangerous until a subject inheriting hepatic porphyria has had an attack after its use. Of course a number of drugs in common use are dangerous, including barbiturate induction anaesthetics, the contraceptive pill, and ethyl alcohol.

SCREENING FOR RAISED FAECAL PORPHYRINS It is essential for this to be carried out on the oldest surviving member of each branch of a family who have inherited the porphyric gene, and their respective progeny must be tested until a clearly proven negative subject is found. Sibs and adult children of any subject inheriting the gene should have their faeces screened on at least two occasions on account of the biochemical variability we have already demonstrated.

\section{ENZYMOLOGICAL INVESTIGATIONS}

It has become increasingly recognised that normal coproporphyrin levels in the faeces do not completely exclude inheritance of the gene ${ }^{16}$ and enzymological studies are particularly useful in three circumstances: (1) to diagnose pre-adolescents who have inherited the gene; (2) to help to confirm or refute the diagnosis where the faecal coproporphyrin analysis is borderline or inconsistent; and (3) to attempt to exclude the inheritance in subjects who have normal faecal coproporphyrin levels but with close relations who have inherited the gene.

\section{EXPLANATION TO PATIENTS}

Explanation of the symptoms of an acute attack must be given to all subjects inheriting the gene together with advice on drugs dangerous to porphyrics. Up to date lists of all drugs, both those thought to be safe and those known to be unsafe, must be available to the family doctor of the porphyric subjects and to the subjects themselves with the doctor's agreement. Those indulging in dangerous activities or sports should be advised to wear Medic Alert bracelets or necklaces.

In many of the above measures the family doctor can play a very positive role, including genetic counselling. Unfortunately strong motivation and ample time is essential as the matter is very timeconsuming. ${ }^{19}$

We would like to acknowledge with thanks Professor $G$ Elder of Cardiff, both for his generous advice and for carrying out the enzymological studies; for carrying out assays on family members living abroad we thank Professor L Eales and Dr B Disler of Cape Town, Mr W Lockwood of Sydney, and Professor G Sweeney of Hamilton, Ontario. We also thank the members of the family for their cooperation and the University of London for a Central Research Fund grant.

\section{References}

1 Dobriner K. Simultaneous excretion of coproporphyrin $I$ and III in a case of chronic porphyria. Proc Soc Exp Biol Med 1936;35:175-6.

2 Watson C, Schwartz S, Schulze W, Jacobson L, Zagaria R. Studies in coproporphyrin III. J Clin Invest 1949;28: 465-8.

${ }^{3}$ Haeger-Aronsen B, Stathers G, Swahn G. Hereditary coproporphyria. Study of a Swedish family. Ann Intern Med 1968;69:221-7.

4 Dean G. Kramer S. Coproporphyria. S Afr Med J 1969; 43:138-42.

${ }^{5}$ Lomholt JC, With TK. Hereditary coproporphyria. $A$ family with unusually few and mild symptoms. Acta Med Scand 1969;186:83-5.

6 Rimington C. Quantitative determination of porphobilinogen and porphyrins in urine and porphyrins in faeces and erythrocytes. Assoc Clin Pathol. Broadsheet No 70, 1971.

7 Eales L, Levey MJ, Sweeney GD. The place of screening tests and quantitative investigations in the diagnosis of the porphyrias with particular reference to variegate and symptomatic porphyria. S Afr Med J 1966;40:63-71.

8 Elder GH, Evans JO, Thomas $\mathrm{H}$, et al. The primary enzyme defect in hereditary coproporphyria. Lancet 1976;ii:1217-9.

9 Elder GH, Evans JO. A radiological method for the measurement of coproporphyrinogen oxidase and utilisation of substrates other than coproporphyrinogen III by the enzyme from rat liver. Biochem $J$ 1978;169:205-14.

10 Ridley $A$. The neuropathy of acute intermittent porphyria. $Q J$ Med 1968;151:307-33.

11 Smith AG, De Matteis F. Drugs and the hepatic porphyrias In: Goldberg A, Moore MR, eds. Clinics in Hematology. Vol 9, No 2. Philadelphia: Saunders, 1980:407.

12 Moore MR. International review of drugs in acute porphyria. Int J Biochem 1980;12:1089-97.

13 Berger H, Goldberg A. Hereditary coproporphyria. $\mathrm{Br}$ Med J 1955;ii:85.

14 Brodie MJ, Thompson GG, Moore MR, Beattie AD, Goldberg A. Hereditary coproporphyria. Q J Med 1977; 46:229-41.

15 Mustajoki P, Koskelo P. Hereditary hepatic porphyrias in Finland. Acta Med Scand 1976;200:171-8.

16 Grandchamp B, Nordmann Y. Decreased lymphocyte coproporphyrinogen III oxidase activity in hereditary coproporphyria. Biochem Biophys Res Commun 1977; 74:1089-95.

17 Cochrane AL, Goldberg A. A study of faecal porphyrin levels in a large family. Ann Hum Genet 1968;32:195-208.

18 Salem SAM, Rajjayabun P, Sheppard AMM, Stevenson IH. Reduced induction of drug metabolism in the elderly. Age Ageing 1978;7:68-73.

19 Andrews J. The Royal Commission. A geriatrician's view. Lancet $1980 ; \mathrm{i}: 87-8$.

Correspondence and requests for reprints to $\mathrm{Dr}$ J Andrews, Department of Geriatric Medicine, West Middlesex University Hospital, Isleworth, Middlesex TW7 6AF. 